\title{
Creating a virtual nursing honor society: Key technology design considerations
}

\author{
Emily E. Hopkins , Debra M. Wolf, Julie D. Slade, Kathleen C. Spadaro, Diane F. Hunker, Michelle Doas \\ School of Health Sciences, Chatham University, Pittsburgh, United States
}

Received: September 13, 2014

Accepted: October 28, $2014 \quad$ Online Published: January 9, 2015

DOI: $10.5430 /$ jnep.v5n2p131

URL: http://dx.doi.org/10.5430/jnep.v5n2p131

\begin{abstract}
The current academic environment is growing exponentially due to online learning. As such, it is important to include outstanding online learners in honor societies for recognition of their academic excellence. Recognizing this need coupled with having no honor society, nursing faculty from a small private university in Southwestern Pennsylvania created a virtual Nursing Honor Society to distinguish their online nursing students' scholarly achievements. Discipline specific honor societies offer an opportunity for students and alumni to maintain a connection to the academic institution, fellow classmates, and alumni for professional networking and continuing education that has not been readily available to programs that provide education to online students. As such, technological strategies for planning and website development are offered to assist other institutions in creating virtual honor societies acknowledging their online learners scholarly achievements.
\end{abstract}

Key Words: Information technology, Honor society, Online learning, Virtual society, World wide web

\section{Introduction}

Development of the World Wide Web (WWW), information technologies, learning management systems, and social media has created the perfect environment for engaging adult students in online learning. Statistics have shown that $87 \%$ of adults use the Internet to search for information. ${ }^{[1]}$ Higher education has tapped into the expanded use of technology to offer online courses for both distance and on-campus adult learners. Based on 2011 Pew Research Center surveys, 89\% of four-year public colleges and universities, $60 \%$ of fouryear private schools, and $91 \%$ of two year colleges offer online classes. ${ }^{[2]}$ Given the growth in online education, it is important to uphold academic traditions such as recognition from an established honor society to acknowledge the nontraditional online student who excels in their area of specialized study. This scholarly acknowledgement can be accomplished through the development of a virtual honor society. However, creating a virtual honor society via the WWW to meet the needs of a virtual community takes careful planning, communication, and collaboration. The purpose of this article is to present the technological processes used to create a virtual nursing honor society (vNHS) as well as provide recommended strategies for success that other institutions may find useful for developing their own virtual honor society.

\section{Background}

With the trend to support lifelong learning in the field of nursing, many nursing schools have developed online nursing degree programs so that nurses can further their education. This educational delivery method allows the nurse to continue to work while providing some flexibility in course participation times. In 2013, the American Association of Colleges of Nursing (AACN) reported a continued increase in the delivery of online undergraduate and graduate degree courses and programs. In three levels of programs surStates.

*Correspondence: Emily E. Hopkins; Email: ehopkins@ chatham.edu; Address: School of Health Sciences, Chatham University, Pittsburgh, United 
veyed, RN-to-Baccalaureate, Master of Science in Nursing, and Doctor of Nursing Practice, $85 \%$ to $90 \%$ provided some online courses in their curriculums and $19 \%$ to $35 \%$ offered fully online programs. ${ }^{[3]}$ With the increased offerings for online education, it is of the utmost importance to have a virtual community or vNHS for recognition of student academic excellence for those who cannot participate in on campus societies. A gap was identified among nursing students in an online educational program indicating that they did not have access to the opportunities afforded members of current on campus honor societies. Nurses who achieve nursing honor society status during their academic years can maintain contact with their alma mater, their classmates, and continue to network during their professional years of practice regardless of their living location through a vNHS.

Creating virtual communities, a place where individuals gather to share common interest or to share information using the WWW, is growing at rapid speed. ${ }^{[4]}$ Today, computers, smartphones, and iPads with internet capability are common types of innovative technologies found in the home and work environment providing endless opportunity to connect with other professionals in real time or asynchronously. One major advantage of virtual communities is the ability to access and visit the virtual site any time of day, seven days a week, from any location around the world that has access to the WWW. Multiple nursing organizations such as the National League of Nursing, American Nurses Association, and Sigma Theta Tau International Nursing Honor Society, to name a few, have turned to the WWW to reach their members in an attempt to support their professional needs. Furthermore, numerous nursing students and professionals are turning to social media such as Twitter, Facebook, LinkedIn, and YouTube to connect, gather, and share information. ${ }^{[5]}$

Given the exponential use of the WWW and social media, and the increasing numbers of distance learners requiring access to campus student offerings, it is important to develop a user friendly site that recognizes academic excellence and promotes communication among members. As such, developing a professional or formal virtual presence is easily achievable when careful planning and collaboration occurs. The purpose of the vNHS was to develop a virtual honor society that recognized academic excellence, provided networking with current students and alumni, and promoted continued learning among online nursing students at a small private university in Southwestern Pennsylvania. Having no formal honor society for their post-licensure nursing programs (RN-BSN, MSN, and DNP), several faculty sought a way to create the university's virtual honor society with the intention of becoming a future Sigma Theta Tau International Society Chapter. This endeavor presented many challenges that required careful planning as well as created many learning opportunities among vNHS founders. Below are key considerations one needs to make when cre- ating a virtual organization such as an honor society.

\section{Implementation planning}

Creating a virtual presence involves many individuals and departments within an academic institution. In order to be successful, careful consideration needs to be given to the overall vision of what the vNHS website should look like, the mission of the vNHS, the resources needed to establish and maintain the website, and the needs of the viewers who will visit the site. Finally, defining what content should be included on the site is critical.

\subsection{Vision}

The nursing faculty at a university in Southwestern Pennsylvania had envisioned the need to create an opportunity where nursing students enrolled in online programs (RNBSN, MSN, or DNP), who excelled in their academic performance, would be acknowledged in a manner that promoted continual growth and professional development beyond the existing academic walls. This organization would also provide an opportunity to network with other leaders within their field as well as nursing alumni.

\subsection{Mission}

After identifying the need for a vNHS, the founding board members defined the mission. The mission focused on a) recognizing superior achievement, b) developing leadership qualities, c) fostering high professional standards, d) encouraging creative work, and e) strengthening commitment to the ideals and purposes of the nursing profession. In order to achieve these five objectives the formation of a virtual community was needed to share information, education, networking opportunities and various tools that would further support and strengthen individual members' ability to perform as leaders within their work environment. Additionally, the vNHS needed a mechanism to support communication between the vNHS Board and current as well as future members of the honor society.

\section{Web site development}

In order to create the vNHS, access to the WWW in the form of a web page was the first priority. Permission was obtained from the University's Web Editor to host the vNHS webpage on their platform. The vNHS needed to have a website that was intuitive, easy to navigate, and organized in a format anyone could utilize. Prior to the actual development of the website, multiple items needed to be considered involving literacy of the targeted audience followed by the actual website design. 


\subsection{Human viewer considerations}

Understanding human interaction with computer use is critical for webpage development. Research has demonstrated that webpages full of unrelated content, including links, stories, and flashing photographs can create severe disorientation resulting in a need for higher cognitive levels of thinking. ${ }^{[6]}$ The vNHS webpage needed to have a basic format that was simple, appealing, and easy to follow. A format that was not overpowering or required a higher level of cognitive thinking was a priority. Three types of literacy were considered when designing the webpage: computer, visual and information literacy.

\subsubsection{Computer literacy}

Although $61 \%$ of adult Americans own a desktop computer and $42 \%$ own a tablet computer, ${ }^{[7]}$ levels of computer literacy will vary among members. Computer literacy refers to an individual's ability to use a computer while searching and utilizing information. Creating a two sectional webpage that included clearly labeled buttons with large amounts of white space, supported individuals with a basic level of computer literacy to navigate the system with ease. Table 1 presents a list of button boxes, titles and a description of content.

Table 1: Button boxes and content

\begin{tabular}{ll}
\hline Button Box Titles & Content Displayed \\
\hline Board of Directors & Photograph, brief biography and board position of each member \\
Programs & List of activities and programs for members \\
Prospective Members & Overview of vNHS for prospective members \\
Current Members & List of member names, email address, current state of residence, area of expertise, and scholarly agenda \\
Induction Ceremony & Audio/Video link to virtual induction ceremonies \\
Board Meeting Minutes & List of minutes from Board meetings \\
NHS Bylaws & List NHS bylaws \\
Committees & List of committees and a description to their role \\
News \& Events & List of news postings or upcoming events \\
FAQs & List of general questions and answers \\
Quick Links & Links to the nursing programs offered at Chatham \\
Contact Us & Contact information of Board Members \\
Toolkits & Tips on how to create Microsoft PowerPoint presentation and Posters \\
\hline
\end{tabular}

\subsubsection{Visual literacy}

Creating a website that was visually appealing, easy to navigate and not over stimulating was a key goal established by the NHS Board. In order to make the site appealing, a warm welcoming banner, forest green in color, was placed on the opening page with the name of the vNHS in larger print underneath the banner. No flashing images or unrelated pictures were utilized. Caution was used to only display content that fully related to the vNHS overall mission. Since the University supported the webpage on their webserver, there was no need for marketing or advertising on the webpage.

\subsubsection{Information literacy}

Knowing how to locate information via a webpage can be challenging for some, especially if their computer skills are extremely weak. The American Library Association (2000) defines information literacy as, "a set of abilities requiring individuals to recognize what information is needed, and the ability to locate, evaluate and use the information effectively"(p2). ${ }^{[8]}$ Using simple/basic titles for button labels organizes information in a way that guides the viewer to easily locate information they are seeking. Keeping large amounts of white space on the webpage assists the viewer in locating information and using it effectively, decreasing complexity

Published by Sciedu Press in viewing information. Finally, most content was written at the Flesch-Kincaid grade level 12.8 (based on readability statistics using Microsoft Word 2013 software). While the members of the vNHS tended to have stronger computer skills as online students, careful attention to organization and usability was still employed.

\section{5 vNHS website quality}

With advanced technology and increased access to the WWW, there has been an explosion of websites created with free access for anyone interested in viewing the sites content. Unfortunately, not all websites are of quality information nor are all websites legitimate and safe. Over the past several years, research has been conducted to create tools to assist the general consumer to evaluate if a website is legitimate or has quality information that is safe to use. In addition, several national organizations have created tutorials and guidelines to guide the consumer. The vNHS webpage needed to be identified by the viewer as a safe site with quality information.

One tested and validated mnemonic tool was created by Dr. Elizabeth La Rue from the University of Pittsburgh. The tool is called SPAT, which is an acronym that stands for Site, Publisher, Audience and Timeliness. ${ }^{[9]}$ By using the Uni- 
versity's web server to host the vNHS webpage, the Site or URL contained the extension ".EDU" which reflects information from an educational institution vs. a "COM" which could be a vendor of any type. Publisher (Nursing Honor Society) is clearly stated for viewers to see as soon as the webpage opens. In addition, as one scrolls down the webpage, a button labeled "Contact Us" is accessible reflecting names and contact information of representatives of the vNHS. Audience is clearly noted within the president's message welcoming nursing students to become members of the vNHS as well as existing members to view information and educational resources. Timeliness refers to date content was posted or updated. As one views the webpage, numerous references are made as to when content was posted, date of meeting minutes as well as dated induction ceremonies and poster presentations.

A national authority in offering guidelines on how to create and/or evaluate a website for quality is the National Institute of Health, National Center for Complementary and Alternative Medicine (NCCAM). ${ }^{[10]}$ The NCCAM advises that individuals should ask five questions when evaluating a website for quality. The questions include who runs the website, why does the site exist, what does the site say, when was the content posted, and where did the information come from. The vNHS clearly addresses each of these questions.

\section{Resources}

In order to be successful in creating and implementing a vNHS, collaboration between multiple departments within the university was essential. Although the vNHS Board consisted of several nursing faculty who spearheaded the development of the vNHS, other key resources were needed. These included individuals from the Information Systems Department (ISD) and the Audio/Visual Department. ISD staff, including the university web editor, were excellent resources to introduce various software programs that could be used to present educational content and information virtually. The founding board was granted access to Contribute (the University's web editing software) for updating and testing web functionality. Access to the University's Contribute software allowed the vNHS to make editorial changes to their webpage in a test environment, reducing the work load and time of the University Web Editor. Once changes were made, the University Web Editor would be notified to review and approve changes. The Web Editor would then release newly updated content into the active web domain for all to view.

Another resource group consulted was the Audio/Visual Department (AVD) at the University. The vNHS would need to deliver a virtual induction ceremony. The ceremony was pre-recorded by staff from the AVD with the nursing founding board members and uploaded to the vNHS webpage for all to view asynchronously at a later date. Members were notified that the ceremony was accessible for viewing through a mass email message.

\section{Recommendations}

Creating the vNHS using the WWW was a challenging, educational, and rewarding endeavor that resulted in an opportunity to recognize academic excellence for online adult learners. In an age where online learning is becoming more prevalent, it is likely that more societies like the vNHS will be created. There are many aspects that need to be considered when developing a virtual society. During the development of the vNHS, lessons were learned that can be shared with future developers. Table 2 offers a few examples of recommendations for success.

Table 2: Recommendations

\begin{tabular}{|c|c|}
\hline $\begin{array}{l}\text { Maintain collaborative and } \\
\text { respectful relationships }\end{array}$ & $\begin{array}{l}\text { Working full time as the University web editor is a time consuming role. Conscious effort was made to request their } \\
\text { time wisely. Careful consideration regarding how the two editors would communicate was established early in their } \\
\text { relationship. The vNHS web editor would only involve the University web editor once content was ready for final } \\
\text { approval and uploading to the active website. }\end{array}$ \\
\hline $\begin{array}{l}\text { Use consistent University } \\
\text { IT staff }\end{array}$ & $\begin{array}{l}\text { When seeking assistance, an effort was made to always work with the same individual who understands how the } \\
\text { software interfaced with the web test environment. Inviting a new person to help trouble shoot issues, may result in } \\
\text { different processes and unnecessary time. }\end{array}$ \\
\hline Use a test environment & $\begin{array}{l}\text { When making changes or updates to the website, a web test environment was used. The web test software was } \\
\text { downloaded onto the vNHS web editor's computer. When various university information system changes were made } \\
\text { or updated, the changes would impact interfaces to the web test software causing the vNHS web editor to receive } \\
\text { multiple error messages in the test environment. This would provide an opportunity for trouble shooting and } \\
\text { resolution of issues prior to implementing on the live website. }\end{array}$ \\
\hline $\begin{array}{l}\text { Provide useful, interesting } \\
\text { content }\end{array}$ & $\begin{array}{l}\text { Deciding on what content was needed on the website and assessing end-user interest was an important step in website } \\
\text { development. A simple survey of members or potential members can garner information about the desired level of } \\
\text { interaction and content. }\end{array}$ \\
\hline $\begin{array}{l}\text { Select a board member with } \\
\text { technology knowledge as } \\
\text { you own web editor }\end{array}$ & $\begin{array}{l}\text { With innovative technology comes a separate vocabulary that individuals not familiar with web design or web } \\
\text { maintenance will not understand. A web editor who is capable of communicating web updates by translating technical } \\
\text { terminology and processes into a simple format is needed for the development of a virtual society. }\end{array}$ \\
\hline $\begin{array}{l}\text { Make sure the site is easy to } \\
\text { use }\end{array}$ & $\begin{array}{l}\text { Efforts were employed to ensure that the website could be easily navigated. Creating a hand drawn map of linked } \\
\text { pathways can help clarify site navigation. Viewing other organizational web pages for ideas can assist as well. }\end{array}$ \\
\hline
\end{tabular}




\section{Conclusion}

With forethought, planning, communication, and a strong team, virtual student organizations and societies can be successfully created within the nursing department along with support from other University departments. Given the growing presence of online programs for distance learners, students need to be offered the same opportunities and recognition as students who attend classes on campus. However, when embarking on this journey there are several key tech- nological considerations and recommendations that should be explored. These key considerations and recommendations for creating an honor society website have been shared along with the vision and experiential process among nursing faculty at a university in Southwestern Pennsylvania who successfully developed a vNHS.

\section{Conflicts of Interest Disclosure}

The author declares that there is no conflict of interest statement.

\section{References}

[1] Fox S, Rainie L. Pew Research Internet Project: Summary of Findings. 2014. Available from: http://www. pewinternet.org/20 14/02/27/summary-of-findings-3/.

[2] Parker K, Lenhart A, Moore K. The digital revolution and higher education. Main report. August 28, 2011. Available from: http://www.pewinternet.org/2011/08/28/the-dig ital-revolution-and-higher-education/.

[3] Fang D, Li Y, Bednash GD. 2012-2013 Enrollment and Graduations in Baccalaureate and Graduate Programs in Nursing. Washington, DC: American Association of Colleges of Nursing; 2013. Available from: http://www.aacn.nche.edu/downloads/ids/20 13/EG12.pdf .

[4] National Council of State Boards of Nursing. White paper: A nurse's guide to the use of social media. Indiana Nurse.2014 Nov, Dec, Jan: 12-15.
[5] Ferguson C. It's time for the nursing profession to leverage social media. J Adv Nurs. 2013; 69(4):745-747. PMid:23488814 http: //dx.doi.org/10.1111/jan.12036

[6] Eshet-Alkalai Y, Geri N. Does the medium affect the message? The influence of text representation on critical thinking. Human Systems Management. 2007; 26(4): 269-279.

[7] Pew Research Center. Device ownership. Available from: http://www. pewresearch.org/data-trend/media-and-t echnology/device-ownership/.

[8] American Library Association. Information Literacy Competency Standards for Higher Education. Chicago, IL: American Library Association; 2000.

[9] La Rue E. SPAT. Website evaluation tool. Available from: http: //www.spat.pitt.edu/research.php

[10] National Institute of Health. Finding and evaluating online resources on complementary health approaches. National Center for Complementary and Alternative Medicine. Available from: http://ncca m.nih.gov/health/webresources . 